\title{
Female Sexual Strategies in the Poetry of Edna St. Vincent Millay
}

Totable for its uninhibited depictions of women's ardency, the poetry of Edna St. Vincent Millay invites readers to reconsider culturally ingrained assumptions about human sexuality. Many of her best-known poems feature female speakers who acknowledge fervent desire: they take pleasure in physical intimacies; they pursue partners actively; they enjoy short-term liaisons; they resist attempts to restrict their erotic experience. Challenging images of women as sexually passive and disinterested beings, Millay's unconventional portraits earned recognition-indeed, notoriety - in a favorable sociopolitical climate. Published largely in the 1920s and 1930s, her work emerged in the wake of a Women's Movement that by 1920 had achieved the goal of universal suffrage. Concern with other kinds of gender-based inequities emerged concomitantly, and women's demands for expanded educational, vocational, and economic opportunities were accompanied by agitation for change in the social sphere. Millay's poetry seemed to support a redefinition of gender roles and expectations, including male-female relationships within and outside of marriage. ${ }^{1}$ Resonating with contemporary social and political issues, Millay's poetry draws attention to important, often unacknowledged, biological facts about female human nature. Worldwide and cross-culturally, strategic interference by men has done much to obscure the full range of women's reproductive behavior by forcibly limiting its expression. In her poetry, Millay highlights some of the preferences women might choose to exercise if male interference, codified in legal and social systems around the globe, ceased to be enforced.

1 She was "a public, contemporary figure who came to represent the new woman and who came to seem the voice of a rebellious generation." Suzanne Clark, "Uncanny Millay," in Millay at 100: A Critical Reappraisal, ed. Diane P. Freedman (Carbondale and Edwardsville: Southern Illinois University Press, 1995), 9. In particular, as Karen L. Kilcup observes, that "rebellious" generation of women "sought freedom from gender roles." Robert Frost and Feminine Literary Tradition (Ann Arbor: University of Michigan Press, 2001), 203. 
Although she sometimes writes in the voice of a specifically named persona (e.g., a character drawn from history or mythology), Millay more often employs unidentified speaking voices whose intimate tones and disclosures tempt readers to assign them autobiographical significance. ${ }^{2}$ From the outset, her fame encouraged readers to interpret her poems as a record of actual experience: she burst upon the scene as an uncommonly attractive and talented young woman seizing sexual freedom in an excitingly Bohemian, post-war world. Her striking physical beauty, which included unusual vocal powers and dramatic gifts, lent extra glamour to her art. Simultaneously scandalized and titillated, her audience tended to confuse her notorious lifestyle with her published work, searching texts of poems to complete their impressions of a charismatic celebrity and, conversely, using information about the poet's life (accurate or otherwise) to annotate and interpret her art. Biographers and critics have to some extent encouraged this tendency, offering evidence gleaned from letters and diaries to identify individual poems, if only speculatively, with romantic partners and events in Millay's life. It is doubtless the case that many of her poems were written in response to real persons and happenings-as is true of many, perhaps most, works of imaginative literature-but autobiographical transparency is not Millay's aim. She does not name her paramours in her poems (there are precious few titles or epigraphs along the lines of "For Ralph" or "To My Husband," for example), nor does she provide contextual clues ("critical particulars of names, dates, and locations") enabling readersin the absence of research-to locate most of her compositions in place and time. ${ }^{3}$ It is reasonable to suppose that, in common with other writers, she exercises artistic liberty in transforming the raw materials of life into art: interpreting, synthesizing, emphasizing, summarizing - in short, distilling "essence" from "Chaos," as she herself puts it, and lending "Order" to the "amorphous shape" of experience ("I will put Chaos," lines, 1, 7, 6). In exploring the evolutionary biological implications of her work, it is particularly important not to confound art with biography. The speakers in Millay's poems are carefully

2 Elissa Zellinger discusses prevailing assumptions that women poets, in particular, were exposing their private selves in their art: these encouraged "the conflation of the woman poet with her poem." "Edna St. Vincent Millay and the Poetess Tradition," Legacy 29, no. 2 (2012): 240.

3 Ann K. Hoff, “'How Love May Be Acquired': Prescriptive Autobiography in Millay's Fatal Interview, CEA Critic 68, no. 3 (2006): 2.

4 Edna St. Vincent Millay, "I will put Chaos into fourteen lines," in Collected Poems, ed. Norma Millay (New York: Harper and Row, 1956). All citations to Millay's poems refer to this edition. Where first lines serve as titles, these have been abbreviated. 
crafted elements in her lyric design. She does not seek to report objectively on the motives and behavior of an actual living woman; rather, she is casting female experience in an imaginative light for purposes of comment and interpretation.

Illustrative disparity between author and speaker can be located very easily in the often anthologized poem "What lips my lips have kissed." In this sonnet Millay speaks in the voice of an older woman in the last stage of her life history, a stage the speaker equates, metaphorically, with "winter" (line 9). It is a cold and "lonely" time, since the amorous adventures of youth, the "summer" of her life, now lie behind her: "summer ... / in me sings no more (lines 13-14). Millay composed this poem in 1919 when she was still a comparatively young woman, twenty-seven years old, and by no means finished with her active sex life. ${ }^{5}$ Creating the figure of an aging, post-sexual woman, she is engaged in a deliberate act of imaginative projection rather than recounting personal history. Written early in her career, "What Lips My Lips Have Kissed" provides clear evidence that Millay consciously crafted literary personae, utilizing "multiple identities" to help shape mood, tone, and theme. ${ }^{6}$ She did not confuse her autobiographical self with the speakers in her poems, although she profited from the inclination of her audience to do just that. ${ }^{7}$

\section{Women's Libido}

In creating speakers and characters of her own sex, Millay insists upon the physically ardent nature of woman. Terms such as "passion," "fever," "burning," and "desire" characterize presentations of women throughout

5 Daniel Mark Epstein, What Lips My Lips Have Kissed: The Loves and Love Poems of Edna St. Vincent Millay (New York: Henry Holt, 2001), 139-40.

6 Clark, "Uncanny Millay," 12. With poems like "What lips my lips have kissed," Cheryl Walker points out, Millay "so shocked and delighted her readers that she became the figurehead of free love culture, a position she exploited for her own use." "The Female Body as Icon: Edna Millay Wears a Plaid Dress," in Millay at 100: A Critical Reappraisal, ed. Diane P. Freedman (Carbondale and Edwardsville: Southern Illinois University Press, 1995), 89.

7 Clark argues that in her public readings Millay invited audiences to view her as the "embodiment" of her poetry and thus to overlook distinctions between "artist and person." "Uncanny Millay," 5. Ann K Hoff makes a similar argument, providing a fascinating account of the relationship between life and art reflected in Fatal Interview. The romance described in this book was, as Hoff's timeline demonstrates, "largely epistolary until after the sonnet sequence was ... published." Millay not only encouraged "the world to question and doubt whether the poems were 'real' accountings of an affair," she endowed that affair in advance with "mythical dimensions," then did "her best to live it as it was written." "'How Love May Be Acquired," 4. 
her oeuvre. Female speakers in her poems describe "the desirous body's heat and sweat," for example, "the fever in the vein," "passion pounding all day long in me," and "love" that resembles "a burning city" ("Yet in an hour to come," line 10; "Peril upon the paths," line 12; "Since I cannot persuade you," line 14; "Women have loved before," line 8). They luxuriate in intimate caresses suggestive of sexual congress: "Enraptured in his great embrace I lie," one speaker proclaims, while another remembers "arms [that] have lain / Under my head till morning" and "lads ... / [who] turn to me at midnight with a cry" ("Olympian gods," line 6; "What lips my lips have kissed," lines 2-3, 7-8). "Almighty Sex," emphasized with a capital "S," sends one poem's speaker "forth at nightfall crying like a cat," eager to indulge admittedly animalistic impulses ("I too beneath your moon," lines 1,2). Comparing herself to a female cat in heat, a breathtakingly defiant analogy, this speaker dissociates herself radically from conventional ideas of female reserve, laying claim instead to sexual impulses of unembarrassed urgency. She goes on to argue that her intellectual or spiritual qualities, no matter how "noble" and "complex," are inextricably intertwined with the physical, erotic side of her nature-namely, her "lust" (lines 8, 14). She makes the case, in sum, that sexuality is a foundational element of female human identity, that it plays a contributing role, however indirectly, in every enterprise.

Millay not only contends that women experience erotic desire, she also indicates that there are no important distinctions between male and female libido. In "Not with libations" she presents a sexually super-charged couple (a "woman and a man"), the "we" of the poem (lines 1, 14). The two are equally "impatient" to enjoy love's "fruits," equally caught up in love's "flame," and equally responsible for permitting physical desire to overwhelm "the altars" of love: together they transform "Love's sacred grove" into "a pasture to the shaggy goats of Pan" (lines 3, 10, 2, 13). They have yielded hastily to the urgency of their desire, seizing "green fruits" without waiting for them to ripen, (line 3, emphasis added). They enjoy a "banquet" instead of more "frugal" pleasures (line 8). Millay does not present the woman conventionally, as the partner with a more idealized conception of attachment or the one whose reticence exercises a braking function on the expression of desire. Rather, the poet makes no distinction between the female speaker and her male companion: she is equally responsible for their headlong plunge into physical intimacy, an intimacy marked as premature and unwise by images and allusions throughout. The poem presents sexual symmetry as a simple fact; there is no suggestion that this is an unusual idea or one for which a case must be made. 
Such depictions of highly sexed women very obviously contradict the feminine ideal persisting in American culture as a legacy of Victorian prudery. Criticizing "her own sexually constricted society," as Holly Peppe observes, Millay contends that "a male monopoly on sexual activity is not only unfair but unnatural." 8 At the same time, moreover, her portrayal of women may appear to undermine the validity of truisms emerging from the field of evolutionary biology. Bateman's Principle posits that sexual reticence tends to serve women's reproductive interests, just as sexual ardor tends to serve men's. ${ }^{9}$ The difference in potential lifetime reproductive success between males and females is used to explain this divergence in sexual behavior. Since women must invest heavily in each reproductive effort, while men's investment is highly variable, women would be expected to be sexually cautious and choosy, waiting for propitious environmental conditions and selecting the highest quality partners available. Because male reproductive success is largely contingent upon access to fertile women, men would be expected to seek out as many reproductive opportunities as possible. Sexual eagerness is a trait that would likely maximize the number of offspring a man might sire: the more partners, the more potential children. This is clearly not true for women: beyond a certain minimum, no increase in partners will increase the maximum number of offspring a woman can produce during her lifetime. An eagerness for many and varied sexual opportunities, consequently, would seem to benefit a woman's fitness much less than a man's. ${ }^{10}$

To avoid oversimplification, it must be remembered that Bateman's analysis of gender differences is used to discuss a wide continuum of behaviors and phenotypes. The variety of sexual strategies available to individuals of either sex necessarily suggests that the stereotypic division of humans into "ardent males" and "reticent females" represents an easy shorthand, intended to summarize a general set of tendencies rather than to draw a line of absolute demarcation between the two sexes. "There is not one reproductive strategy for women and another for men," David C. Geary points out, "as the strategies

8 Holly Peppe, "Rewriting the Myth of the Woman in Love: Millay's Fatal Interview," in Millay at 100: A Critical Reappraisal, ed. Diane P. Freedman (Carbondale and Edwardsville: Southern Illinois University Press, 1995), 58.

9 Buss, Evolution of Desire, 76-78.

10 David A. Frederick, Tania A. Reynolds, and Maryanne L. Fisher, "The Importance of Female Choice: Evolutionary Perspectives on Female Mating Strategies," in Evolution's Empress: Darwinian Perspectives on the Nature of Women, ed. Maryanne L. Fisher, Justin R. Garcia, and Rosemarie Sokol Chang (Oxford: Oxford University Press, 2013), 307-08. 
adopted by women and by men often vary across contexts and across historical periods." "Evolutionary accounts that emphasize the sexually indiscriminate male and the sexually coy female overstate the case," Buss cautions. ${ }^{12}$ Pointing to recent research, David A. Frederick and his colleagues note that "the strongly held view that females were passive and coy" has begun "to fall to the wayside" in contemporary evolutionary thinking. ${ }^{13}$ Like men, women can and do employ short-term sexual strategies. Men's tendency toward promiscuity may be more pronounced than women's, but, as researchers have been quick to point out, men could not engage in fleeting liaisons or extramarital affairs without a sufficient supply of women available to serve as short-term partners. ${ }^{14}$ When considering the notion of female reticence, moreover, it is crucial to realize that sexual cautiousness does not necessarily indicate either an absence of desire or the inability to feel sexual pleasure. As David J. Buller and others observe, a complete disinterest in sexual activity could scarcely serve the evolutionary interest of members of any mammalian species. For women, as well as for men, "the 'sex drive' ... is an adaptation" designed to promote reproductive success. ${ }^{15}$ Investigating sexual assertiveness in human and non-human primates, Sarah Hrdy has gathered compelling evidence that females are far less "coy" than often is assumed. ${ }^{16}$ Almost certainly there has been some "selection in women for sexual desire": it is associated with evolutionary advantage. ${ }^{17}$

Hrdy goes on to argue that male interference, motivated by the wish to monopolize female fertility and ensure paternal certainty, has played a large role in shaping the myth of women's sexual disinterestedness. Physical violence and coercion, reinforced by social prescriptions, operate as effective constraints on the expression of female desire. ${ }^{18}$ The lengths to which men have gone to restrain female sexuality indicate very clearly that there is something to

11 David. C. Geary, Male, Female: The Evolution of Human Sex Differences (Washington, D.C.: American Psychological Association, 1998), 151.

12 Buss, Evolution of Desire, 215.

13 Frederick, Reynolds, and Fisher, "The Importance of Female Choice," 310.

14 Buss, Dangerous Passion, 159.

15 David J. Buller, Adapting Minds: Evolutionary Psychology and the Persistent Quest for Human Nature (Cambridge, MA: The MIT Press, 2006), 294.

16 Hrdy, Mother Nature: 42, Sarah Blaffer Hrdy, The Woman That Never Evolved (Cambridge, MA and London: Harvard University Press, 1981), 172-80.

17 Hrdy, Mother Nature, 224.

18 Ibid., 258-63; Hrdy, Woman That Never Evolved, 177-80. 
be restrained - that is, that women are not nearly so passionless as husbands or harem-holders might wish. Sequestration, veiling, foot-binding, and clitoridectomy, along with less extreme tactics utilized by men to suppress women's sexuality, would not be needed if women truly lacked libido, or if they seldom indulged in extramarital affairs. 19 "Women's readiness to engage in sexual activity is great enough," Hrdy points out, "that the majority of the world's culturesmost of which determine descent through the male line-have made some effort to control it." ${ }^{20}$ The "expectation of female promiscuity" - an expectation that belies socially promulgated views of womanly reserve-has exercised a critical shaping effect on social institutions historically and cross-culturally. ${ }^{21}$

David M. Buss summarizes the situation, noting that "men tend to control resources and power worldwide"; they use their economic and political advantage to exercise domination over women, with special emphasis on women's sexual behavior. ${ }^{22}$ Aggression figures heavily in men's efforts to dominate women, "not because men are inherently aggressive and women inherently submissive," as Barbara Smuts argues, but because physical force has proven to be an especially reliable tactic, given human sexual dimorphism, in men's ongoing struggle to "enhance their reproductive opportunities." 23 Men compete with one another for access to women, who represent the limiting resource in human reproduction. Those men who acquire and defend exclusive rights to fertile females tend to leave the largest genetic legacies. As Buss states, "we come from a long and unbroken line of ancestral fathers who succeeded in obtaining mates, preventing their infidelity, and providing enough benefits (or inflicting enough deterrent costs) to keep them from leaving." 24 In the arena of mating, male control frequently is enforced by legal codes and social penalties, as well as by physical coercion. The internalized restraints forged in modern Western societies by defining women as inherently chaste, faithful, and passionless-interested in emotional rather than

19 See Hrdy, Mother Nature, 262-63 as well as discussion by Smuts, “Male Aggression," 255.

20 Hrdy, Woman That Never Evolved, 177; Frederic, Reynolds, and Fisher, "The Importance of Female Choice," 321.

21 Hrdy, Mother Nature, 177 (Hrdy's emphasis).

22 David M. Buss, "Sexual Conflict: Evolutionary Insights into Feminism and the "Battle of the Sexes," in Sex, Power Conflict: Evolutionary and Feminist Perspectives, ed. David M. Buss and Neil M. Malamuth (New York and Oxford: Oxford University Press, 1996), 297, 299.

23 Smuts, "Male Aggression," 256.

24 Buss, "Sexual Conflict," 309. 
physical manifestations of attachment-operate with especial subtlety to limit women's sexual activity.

In this context of long-standing denial and suppression, Millay's portraits of sexually assertive women assume biological as well as political interest. Deliberately and, indeed, provocatively challenging notions of female sexual reticence, the poet offers important correctives to reductive theorizing as well as to cultural stereotyping. Her work lends the not inconsequential weight of art to the "numerous pieces of evidence" now emerging in the fields of evolutionary anthropology, zoology, and psychology to support "the idea that females are very active players in the mating game, contrary to assumed wisdom." 25 "It is in works of imagination," Joseph Carroll points out, "that people articulate the quality of their experience, make sense of it, and feel its significance and value." 26 To underline her chosen themesthe "sense" she makes of human experience-Millay favors hyperbole, frequently supported by irony and wit. In character and in situation, she exploits the power of exaggeration to command audience attention. Her recklessly passionate female personae pose defiant contrast to the ethereal conceptions of womanliness prevailing in her social environment.

The well-known sonnet beginning "I, being born a woman" epitomizes Millay's hyperbolic approach to her subject matter. The speaker lays claim to feelings and intentions precisely like those associated with male seducers of the Don-Juan type. She enters into sexual intimacy with "zest," allowing passion temporarily to dominate her sensations, that is, to "cloud the mind" and "leave [her] undone" (lines 4, 7, 8). Even as she yields to sexual ecstasy, the "treason / Of my stout blood against my staggering brain," however, she assures her partner that the shared pleasures lack emotional content (lines 9-10). "Think not for this," she cautions, that "I shall remember you with love" (lines 9, 11). She rejects the possibility of any meaningful aftermath to the "frenzy" that momentarily has united them: sexual bonding supplies "insufficient reason" for continuing social intercourse, including even the niceties of "conversation" (lines 13, 14). This sonnet is justly famous for its breathtaking reversal of traditional ideas about women. Its speaker not only revels in physical passion but

25 Christopher J. Wilbur and Lorne Campbell, "Swept off Their Feet? Females' Strategic Mating Behavior as a Means of Supplying the Broom," in Evolution's Empress: Darwinian Perspectives on the Nature of Women, ed. Maryanne L. Fisher, Justin R. Garcia, and Rosemarie Sokol Chang (Oxford: Oxford University Press, 2013), 341.

26 David Sloan Wilson and Joseph L. Carroll, "Darwin's Bridge to the Humanities: An Interview with Joseph L. Carroll,” This View of Life (The Evolution Institute: 2016). Web. 
ruthlessly dissociates sex from love, treating her partner with offhanded contempt. He serves as an instrument of her sexual satisfaction and nothing more. Instead of letting him down gently, moreover, the speaker delights in telling him exactly how little he means to her.

If these sentiments had been articulated by a male speaker, they would seem unusual only because of their brutal honesty. When men exploit women sexually, typically they express affection or gratitude even if they have no intention of pursuing the relationship: the man who promises to "call" but never does is a familiar stereotype. Millay's speaker does not comply with the custom of empty assurances, going out of her way instead to humiliate her partner. Thus she underlines via exaggeration the scantily disguised selfishness with which men often exploit women. The sarcasm directed toward the male addressee effectively counters expectations familiar from literature and opera, as well as from folklore, that women will cling desperately, and "with love," to any man with whom they have enjoyed physical intimacy (line 11). Here it is the female partner who feels "scorn" (almost but not quite tinged with "pity") for a man she is heartlessly discarding (line 12). Sex itself is presented wholly without reverence: the term "frenzy" suggests a maddened lust stripped of redeeming significance or exaltation. Readers encounter a woman who regards sex neither as terrifying contamination nor as romantic fantasy. She has the temerity to claim, furthermore, that her susceptibility to sexual passion occurs because of her gender, rather than despite it. "Being born a woman," she finds herself responding, irresistibly, to the physical "propinquity" of a man, yearning to feel his "body's weight upon [her] breast" (lines 1, 3, 5). She cannot help being stirred by "the needs" of her female "kind" (line 2).

Thematic statement in the poem is highlighted by Millay's parodic appropriation of the love sonnet, a genre used by male speakers to woo beautiful, sexually reticent women. ${ }^{27}$ Traditional expectations of gallantry are subverted as Millay's speaker articulates motives that typically remain unspoken by male counterparts: she is sexually hungry, intent upon physical gratification rather than emotional

27 Stacy Carson Hubbard points out that the "various roles" Millay "mimics and manipulates are the rhetorical products of a specific discourse (lyric poetry, and more specifically ... the tradition of the carpe diem sonnet)." 'Love's 'Little Day': Time and the Sexual Body in Millay's Sonnets," in Millay at 100: A Critical Reappraisal, ed. Diane P. Freedman (Carbondale and Edwardsville: Southern Illinois University Press, 1995), 101-102. For further analysis of Millay's purposes as she "inverts the usual place of the woman in Petrarchism," see Natasha Distiller's commentary in Desire and Gender in the Sonnet Tradition (Houndsmills, England and New York: Palgrave Macmillan, 2008), 154. 
investment or future commitment, and she uses her gender to excuse her lustfulness. Sex does not bind her: she is in no way dependent upon her partner and his future good will. Behind the speaker's disdain, readers sense a certain auctorial glee: Millay appears to enjoy ascribing to a woman sexual appetites and prerogatives typically defined as male. More important than this speaker's ardor, even, is the dominant role she plays. There is a triumphant, 'ha ha, gotcha' element in the poem that goes far to explain its powerful effect. Its speaker overturns popular ideas about women's sexual nature with cool detachment.

Putting forward the proposition that women can function as sexually active and autonomous agents, a poem like this one courts intense reactions: readers may be horrified, offended, or thrilled, but response scarcely will be bland. In addition to questioning socially approved views of female sexuality, Millay targets for attention a fundamental source of conflict between men and women: autonomy per se. From an evolutionary biological perspective, men's domination of women appears to be "part of a psychological profile derived from their normative reproductive strategy," but that strategy comes into direct conflict with "the basic human desire for autonomous individuality." ${ }^{28}$ Millay creates a fictive situation in which the tables are turned, and it is a woman who exercises dominance over a man. Female sexual appetite, combined with deliberately short-term involvement, is the only explanation (direct or indirect) that the poem offers for this reversal. By implication, the poem identifies the myth of women's sexual disinterestedness as fraudulent, a tool of wide-ranging political and social oppression.

\section{Short-term Strategies}

Unsurprisingly, Millay extends her presentation of female agency into the realm of sexual promiscuity. She composes numerous poems from the perspective of women engaged in short-term mating strategies. "To the Not Impossible Him" suggests, wittily but decisively, that women's much-vaunted predilection for sexual loyalty is not innate, but rather a byproduct of their limited experience. Those who never travel are unable to make comparative judgments, the speaker points out. "How shall I know, unless I go / To Cairo and Cathay," whether opportunities in myimmediate environment are indeed “blesséd”? (lines 1-2,3).

28 Nancy Easterlin, "From Reproductive Resource to Autonomous Individuality? Charlotte Bronte's Jane Eyre," in Evolution's Empress: Darwinian Perspectives on the Nature of Women, ed. Maryanne L. Fisher, Justin R. Garcia, and Rosemarie Sokol Chang (Oxford: Oxford University Press, 2013), 391. 
A provincial outlook fosters local preference, obviously, and such preference is relatively meaningless so long as it remains untested. Until she smells "the Carthaginian rose," how can the speaker be certain that the right "flower" for her is the one here "beneath [her] nose"? (lines $8,5,6)$. In the third and final quatrain, the speaker expands her metaphor explicitly into the realm of "faithful love," which "no power shall dim or ravel / Whilst I stay here" (lines 9, 10-11). If, however, she "should ever travel," she saucily declines to answer for her future fidelity (line 12).

Geography and travel serve as metaphors in this poem for a host of customs and norms restricting women's experience. Their physical, intellectual, social, and sexual activities are limited by gender-specific rules and prohibitions. Such culturally imposed constraints prevent women from making comparisons among men and exercising selective discrimination in their mating efforts. They are satisfied, and hence faithful, because they are denied access to varied and possibly more attractive mating options or strategies. Mention of exotic destinations like Cathay highlights the freedom with which men move in the world, physically and socially. If women were permitted comparable adventuring, Millay's poem suggests, they might behave as promiscuously as men. The right to an unfettered, autonomous existence might mean that women would move from "flower" to "flower," enjoying a variety of partners. Empowerment in the social sphere, this poem implicitly argues, might well undermine female fidelity. Women who are allowed to "travel," sexually speaking, will discover an ever-changing array of alternatives to explore.

Continuing to question the stereotype of female constancy, another of Millay's female personae emphasizes the appeal of novelty. She describes her eroticism in crudely powerful terms as a "beast that rends me," but the strength of her desire does not lend it endurance (“This beast that rends me," line 1). Soon, as past experience evidently informs her, this passion "will glut, will sicken, will be gone"; "the fever will abate" (lines 4, 5). She will "forget" her current lover, even though "today" he is mightily important: her "east and west" (lines 7,8$)$. Another character, similarly aware of her restless sex drive, declares that she is "faithful" to its gratification rather than to any individual partner ("Oh, think not I am faithful," line 1). She stays with her current paramour, she tells him, only because he "still" represents "hunger's rarest food," sexually speaking, and can slake her "wildest thirst" (lines 5, 6). If he ceased to meet her erotic needs, she declares, "I would desert you ... / And seek another as I sought you first" (lines 7-8). She defines herself unblushingly as a woman for whom sexual satisfaction is paramount. Because her temporary partner is as "wanton, 
light and false" as she, the speaker furthermore argues that her departure, once their passion is spent, will serve his needs as much as hers. Loyal to the shifting object-choice of human lust, she is, paradoxically, "most faithless when ... most ... true" (line 14).

In the already mentioned "What lips my lips have kissed," Millay presents a short-term strategist who has led an active sex life devoid of long-term attachment. She has "forgotten" individual details about the many "unremembered lads" with whom she has shared sexual pleasures (lines 2, 7). Because they are so numerous, and emotionally so unimportant to her, she cannot recall "where, and why" she happened to take up with any of them (line 1). In the first line of the poem these short-term partners are reduced to body parts ("lips"), emphasizing their role in providing physical satisfaction. Here Millay employs hyperbole to stress the erotic component of female identity. Her female speaker's powerful libido defies conventional assumptions, as does her inclination to seek sexual gratification in brief encounters. Depicting a woman who conducts her sex life along lines typically regarded as masculine, the poet indirectly affirms sexual symmetry.

The sonnet's sestet, which introduces the analogy between aging woman and "lonely" tree, is particularly significant because it places the speaker's experience in the context of natural processes. The tree is "lonely" in winter because the birds that sang in its boughs all summer have "vanished" (lines 9, 10). (Like the human speaker, tellingly, the tree does not remember individuals: "nor knows what birds" have come and gone [line 10].) It is natural for birds to migrate in winter; it is equally natural for humans to reduce their sexual activity as they age. These are normal effects of seasonal progression, including progression of the metaphoric seasons typically invoked to characterize phases in human life history. The speaker's loneliness in later life is not a penalty for promiscuity, Millay's chosen analogy indicates, but a natural result of the passage of time. As Suzanne Clark points out, the poet typically describes "the shape of a love affair" as "a repeated cycle, from beginning to inevitable end." ${ }^{29}$ Although tone in the poem's final lines is gently regretful, the speaker's regrets are focused on the loss of youth and its lusty pleasures; she expresses no dissatisfaction with her earlier behavior or strategic choices.

Numerous poems similarly defend short-term strategies by comparing sexual passion to biological inevitability: growth followed by decay. Organic life moves through developmental stages, each generally brief in duration. Human

29 Clark, “Uncanny Millay,” 22. 
passion similarly will flourish, temporarily, then decline. Such considerations lead to a philosophical rejection of long-term expectations. What makes sense, in the face of continuous change, is to maximize the pleasures of the moment. "Mark the transient butterfly, / How he hangs upon the flower," the speaker in "Mariposa" advises her companion (lines 7-8). The short lifespan of the insect does not diminish the intensity with which it enjoys present gratification of its appetite. The human lovers should model themselves on this example by acting on their physical impulses, the speaker counsels; "suffer me to take your hand" (line 3). Repeating, hyperbolically, that "death comes in a day or two," she advocates the immediate consummation of desire: "Suffer me to cherish you / Till the dawn is in the sky" (lines 4, 10-11). Her arguments recall those articulated by male poet-speakers trying to shock reticent women into abandoning sexual reserve: Marvell's “To His Coy Mistress” with its threats of tombs and worms, comes at once to mind. Here in "Mariposa" (yet another poem in which Millay affirms sexual symmetry) it is the woman who emphasizes that "all the things we ever knew / Will be ashes" soon, and who offers the imminence of death as a reason to indulge in casual sex (lines 5-6). In the face of life's brevity, she avers, questions of obligation and fidelity are irrelevant: "Whether I be false or true, / Death comes in a day or two" (lines 12-13).

Millay's understanding and acceptance of change is cosmic in its reach. In "O Earth, unhappy planet," for example, she emphasizes the process of evolution over time, referring to the extinction of species as inevitable. In the larger scheme of things, the human race will occupy only a tiny fraction of planetary time, "an hour" (line 6). No matter how "bright" his achievements, or how "high" his destiny, Homo sapiens will go "down into the sea" like a setting sun, unremembered (lines 6, 4, 7). Earth itself eventually will disintegrate, since it was "born to die" (line 1). Tempting though it is to regard man as special because of his emotional, technological, moral, and aesthetic capacities ("his singular laughter, his droll tears, / His engines and his conscience and his art"), in the end he is simply one "animal" among many (lines 11-12, 14). Emerging from "the catholic slime" that once "cradled" a host of now-fossilized creatures, the human race soon will disappear into the "ooze" from which it "but lately crawled" ("Cretaceous bird," lines 5, 13, 14). Millay demonstrates conscious awareness of nature's indifference to the survival of individuals and of kinds, including the dispassionate workings of natural selection. She grounds her ideas about human sexuality in these larger, evolutionary understandings, implicitly arguing that short-term strategies make philosophical, emotional, and practical sense in the face of death and extinction. 
Her focus on the transience of all earthly things provides Millay with a doubly useful philosophical framework: justification for promiscuity and infidelity as well as consolation for any suffering such behaviors may cause. Her readers seldom encounter the warmly hopeful feelings typically associated with love poetry. The pervasiveness of multiple, simultaneous involvements adds to uncertainties posed by the evanescence of desire:

We meet and part;

Our talk is all of heres and nows,

Our conduct likewise; in no act

Is any future, any past;

Under our sly, unspoken pact,

I know with whom I saw you last,

But I say nothing; and you know

At six-fifteen to whom I go.

(“Theme and Variations" IV, lines 3-10)

"Tell me, can love go on like that?" this speaker demands of her partner (line 19). The result of so much casual promiscuity, she avers, is a "bored, insulted heart" (line 20). Even as she lays claim to gender parity, she is inclined to disparage the jading effects of the equal-opportunity infidelity she reports. Another speaker admits that the experience of "a love turned ashes" represents a terrible disappointment, far worse than seasonally imposed endings ("April ... shattered" or "August ... levelled"): it proves much more difficult to recognize that "a dream can die" ("Here is a wound," lines 3, 9, 10, 13).

Since the principal characters in the poems almost invariably are female, the experiences of disappointment some of them acknowledge suggest at times that men's ardor may be more fleeting, even, than women's. The muchanthologized sonnet beginning "Pity me not" offers support for that supposition. In its reassuringly rhythmic presentation of earthly transience, it focuses first on elemental phenomena: gravitational forces affecting astronomical bodies, like the ebb and flow of oceanic tides, illustrate unremitting change. The moon is "waning"; "the year goes by"; all is "shifting" (lines 5, 4, 11). The octave concludes with an unanticipated reference to human feeling, which is slipped into the list as yet another manifestation of evanescence. Initially the poem appears to be an impersonal meditation on the theme of change, but suddenly it grows more subjective in focus. An addressee emerges, the man whose "desire is hushed so soon," and the speaker reveals herself as the former 
recipient of his affections: "you no longer look with love on me" (lines 7, 8). Here Millay singles out "a man's desire," rather than a woman's, to illustrate the impermanence of human passion. His inconstancy must be regarded, the poem's speaker nevertheless concludes, as simply one more instance of a larger ruling principle. She admits she finds it hard to shape her wishes in conformance with nature's ways, to accept the inexorable progression from "blossom" to "wreckage" (lines 10,12). It is easier to recognize than to welcome the inevitable transience of all things, including erotic desire. Intellectual understanding does not guarantee emotional acquiescence: "the heart is slow to learn / What the swift mind beholds at every turn" (lines 13-14).

As such examples show, the yearning for a longer lasting "love" sometimes emerges despite the carpe diem philosophy permeating the poetry. Such yearning appears to indicate that woman's evolved potential for implementing long-term mating strategies cannot be completely suppressed. Vestiges remain, sometimes casting a shadow on the short-term strategies presented in the poems as natural and workable alternatives. For the most part, Millay's female characters do not permit themselves to expect what they acknowledge to be impossible. Elizabeth P. Perlmutter observes that "at the very moment of heartbreak" (following "reckless" surrender to "some heartless lad"), Millay's personae draw on reserves of "a terrible strength." 30 When their emotional equilibrium is threatened, the provisional nature of all organic and elemental phenomena provides them with consoling context and chin-up corrective:

The love that stood a moment in your eyes,

The words that lay a moment on your tongue,

Are one with all that in a moment dies,

A little under-said and over-sung.

(“I shall go back again,” lines 9-12)

Thrown off balance by the abrupt departure of a lover, the speaker in this poem defends herself from pain with biting wit, squelching her disappointment with a jibe at high-flown praise of experiences destined to be momentary. Reluctantly or mockingly, Millay's women nearly always insist on the irremediably temporal limits to desire. Thus they profit from the liberating "momentum" inherent

30 Elizabeth P. Perlmutter, "A Doll's Heart: The Girl in the Poetry of Edna St. Vincent Millay and Louise Bogan," Twentieth Century Literature 23, no. 2 (May 1977): 160. 
in a "feminist embrac[ing] of the ephemeral." 31 Their avowed goal is to experience the joy of passion stripped of demands for continuance or exclusiveness: "love in the open hand" ("Not in a silver casket," line 9).

"I shall forget you presently, my dear," one speaker impudently assures her lover ("I shall forget you presently," line 1). There is discernible disdain in her voice as she advises him to "make the most of this, your little day" (line 2). Meanwhile the two of them will exchange protestations of commitment, though both know these are meaningless: "your loveliest lie" and "my favourite vow" (lines 7, 8). She wishes, the speaker continues, that "love were longerlived / And oaths not so brittle," but since "nature has contrived" otherwise she accepts the inevitable: "so it is" (lines 9-10, 11). "Biologically speaking" she remarks at the sonnet's conclusion, their happiness is "idle," or irrelevant (line 14). Here Millay comes close to articulating Darwinian insights in twenty-first-century terms, observing that nature's contrivances (e.g., adaptations) are designed to promote evolutionary ends (i.e., fitness) rather than personal contentment. She recognizes, in effect, that sexual activity represents a response to proximate impulses keyed to reproduction, that is, sensations of desire flourish even in the absence of a conscious intention to create offspring. The pleasures these lovers "presently" share are inspired by biological forces over which they have no control. By making sex irresistibly appealing, "nature" has managed "to struggle on without a break" (lines 11, 12). Millay does not go on to ask whether yearnings for long-term commitment also might prove adaptive but focuses instead on sexual desire itself, which is limited in duration and intensity, fluctuating in object-choice. The recognition in the poem's final line that there is a biological purpose to sex is, in itself, rare in her work. The women she portrays do not appear to have or anticipate offspring, nor is conception mentioned as a possible byproduct of the erotic "frenzy" in which they indulge.

31 Geffrey Davies, "Edna St. Vincent Millay's A Few Figs from Thistles," Textual Cultures 9, no. 1 (2014): 88. As Janet Gassman accurately points out, "the poems in which she is abandoned are not ... nearly so numerous as those in which she is fleeing some over-possessive admirer or ... cautioning a lover not to magnify the permanence and significance of a passionate physical attachment.” “Edna St. Vincent Millay: 'Nobody’s Own,” Colby Library Quarterly 9, no. 6 (June 1971): 305. 


\section{Costs and Benefits}

Readers cannot help noticing that in the fictive world of Millay's poems there is no mention of the costs women ordinarily incur, or risk incurring, when they employ short-term sexual strategies. ${ }^{32}$ Most obviously, none of Millay's women become pregnant, nor do they express worry about such an eventuality. This eliminates at a stroke the most serious of the possible costs to women associated with commitment-free liaisons, namely, the prospect of bearing and rearing a child without paternal assistance. The risk of sexually transmitted diseases, which increases exponentially with numbers of casual sex partners, likewise garners no mention. Millay's women express no fear of violent retaliation at the hands of rejected or discarded partners or, for that matter, at the hands of jealous wives, girlfriends, or ex.'s. The potential loss of a long-term partner, together with the resources he provides, frequently deters women from promiscuous behavior, but Millay's characters typically describe a lifestyle predicated upon brief and uncommitted relationships; hence, they view frequent turnover in partners as natural and unavoidable. They show no eagerness to obtain access to the material resources or social advantages that affairs with prosperous, high-status men could provide.

Millay lived and wrote, of course, before truly reliable forms of contraception became available to women, yet she never acknowledges that she is ignoring biological facts. If women played no role in reproduction, men would have no need to control or coerce them, sexually or otherwise. Most of the genderbased problems women experience would be eliminated: no longer would they represent a resource to be exploited and hoarded. If women's sexual freedom exerted no impact on men's genetic legacy, it follows that men would gain nothing by inhibiting it. The liberty Millay's characters enjoy is predicated, at least in part, upon counterfactual suppositions, and these are neither explained nor discussed in the poems. There is, likewise, no mention of possible connections between the sexual freedoms the poet celebrates and the goals of birth-control activists like Margaret Sanger. ${ }^{33}$

When sexual activity is closely tied to reproduction-as in real lifemuch of men's controlling behavior, vis-à-vis women, is motivated by the desire

32 For a summary of these costs, see Buss, Evolution of Desire, 235.

33 Biographer Daniel Mark Epstein comments that Millay offered the embattled Sanger, "patron saint of birth control," neither public nor private support during critical legal battles in 1917. What Lips My Lips Have Kissed, 123. 
to avoid misplaced paternal investment. ${ }^{34}$ Women with long-term mates often are subjected to elaborate mate-guarding tactics, including abuse or desertion by jealous partners. "In virtually all the world's cultures," as Smuts observes, "mating rights entail ... the exclusion of other men from sexual access to a man's wife." 35 Virtually none of the women depicted by Millay submit to such suffocating conditions. Her most elaborate portrait of a married woman can be found in the sequence of sonnets comprising Fatal Interview. The female speaker recounts a history of adulterous passion, focusing chiefly on her lover. Directly and indirectly, she reveals that the threats her infidelity poses to her marriage are, in her view, negligible. Although she anticipates that the affair will disturb her relationship with her husband ("this encounter like a sword / Will lie between me and my troubled lord"), she expresses no worry that he will abandon her or resort to violence ("This beast that rends me," lines 13-14). She describes a long-term union unencumbered by male jealousy and possessiveness, an unusual arrangement that evidently grants her more sexual freedom than most wives enjoy. ${ }^{36}$

She boasts, in Sonnet \#26 from the sequence, that she lives and loves in the manner of legendary, high-status women like Helen and Guinevere. Acting on what she describes as "unregenerate passions," she compares herself to "treacherous queens" who "took their knights to bed" with no regard to consequences ("Women have loved before," lines 12, 13). Like powerful women of mythic stature, she is "heedless and wilful" in her extramarital adventuring; she abandons herself to "love" in an "utter, ancient way" (lines 14, 8, 10). Through this voice, Millay emphasizes the untamable nature of erotic desire, which can override religious ethics or personal integrity — as terms such as "unregenerate" and "treacherous" indicate. Sexual urgency appears to foster an uncompromising focus on self, a determination to assign priority to the "burning" in one's own "breast" (line 8). The persona in this sonnet does not acknowledge that the female figures to whom she alludes did, in fact, pay a price for marital infidelity, or that their "heedless" behavior triggered collective violence and

34 Steven W. Gangestad, "Evidence for Adaptations for Female Extra-Pair Mating in Humans: Thoughts on Current Status and Future Directions," in Female Infidelity and Paternal Uncertainty" Evolutionary Perspectives on Male Anti-Cuckoldry Tactics," ed. Steven M. Platek and Todd K. Shackelford (Cambridge and New York: Cambridge University Press, 2006), 42.

35 Smuts, "Male Aggression," 246. See also 239.

36 Pratto discusses the physical punishments, up to and including murder, that form part of traditional male mate-guarding tactics. "Sexual Politics: The Gender Gap," 203. 
cultural upheaval. Certainly she foresees no harsh consequences in the case of her own adultery. She does not fear physical harm to herself or to her extrapair partner, nor does she anticipate that her husband will restrict her personal freedom in future by stepping up his mate-guarding efforts. Her suffering, noted intermittently throughout the sonnet sequence, is occasioned solely by desperate wishes that the affair, always defined as impermanent, might last longer-perhaps "a summer more" — than it does ("Well, I have lost you," line 10).

The possibility of sexual assault, inherent in the greater physical strength of men and abetted by sociopolitical power structures favoring male prerogatives, does not worry women in Millay's poetry, as modifications she makes to a classical myth in the poem "Daphne" illustrate. In the original version, Daphne is a young woman fleeing from the god Apollo, a high-status male intent on coercive sex. The transformation of girl into tree, an act of rescue performed at the last minute by her father, is presented as an unexpected resolution to her predicament. In Millay's new version, Daphne shows foreknowledge of her escape: at "any moment," she taunts Apollo, she can frustrate him by becoming "nothing but a laurel-tree" (lines 2, 3). This is not the desperately frightened girl from classical mythology. Millay's Daphne is certain from the outset that she will not be forced into sexual submission. Because of this certainty, the chase holds no terrors for her; she treats it as a game that she is bound to win. Her final words to Apollo indicate that she takes some pleasure in leading "over hill and hollow" a foolishly lust-driven man who fails to realize that he never can possess her (line 7). In response to his obstinate "will to follow," she sets forth, calling to him as if he were a dog: "I am off;-to heel, Apollo!" (lines 8, 9).

Here Millay has incorporated obviously wish-fulfilling elements into familiar materials, depicting a woman who does not depend upon others to rescue her from a sexual predator. This new Daphne emphasizes her own power ("I can," "I can") rather than any need for a father's protective intervention (lines 2, 5). ${ }^{37}$ Transformation into a relatively insensate life form, a tree, may serve as the metaphoric equivalent of the emotional detachment so many of Millay's women cultivate as part of their strategy to retain control in their relations with men. Otherwise, the poem does not point to any real-world mechanisms or

37 See Geffrey Davies and also Catherine Keyser for related analysis of feminist themes in this poem. "Edna St. Vincent Millay’s A Few Figs from Thistles," 85-86; Playing Smart: New York Women Writers and Modern Magazine Culture (New Brunswick, NJ: Rutgers University Press, 2011), 40. 
conditions that would render young women invulnerable to sexual attack from physically and socially powerful men. It succeeds admirably in communicating how much women would stand to gain if such unreal conditions in fact prevailed. In a world where men did not threaten their sexual choice or autonomy, women could move about at will, calling men "to heel" as necessary.

Just as there are no physical costs in Millay's poetry to uncommitted sex, in terms of pregnancy, disease, coercion, or assault, there are no social costs. Her female characters express no anxiety about damage to their reputations or diminished support from family and friends. They say nothing about possible community shunning or reduced status. Such penalties, as discussed earlier, have been employed historically and cross-culturally to control women's sexual behavior. Women who engage in premarital or extramarital sex of any kind typically reduce their chances of marrying well. If already married or otherwise committed, they risk the loss of current partners along with violently jealous retaliation. Typically, they forfeit access to resources, which threatens their survival and that of offspring. They are liable to become objects of public opprobrium and familial condemnation. ${ }^{38}$ Outside the realm of wish-fulfillment, as Millay's readers necessarily recognize, women who engage recklessly or repeatedly in short-term affairs are apt to wind up with offspring they cannot support, impoverished and reviled, possibly victims of physical battering or venereal infection as well. None of these consequences are experienced or, indeed, even anticipated by women portrayed in Millay's works. Socially, as well as biologically, the poems silently ignore the risks associated with casual sex.

Although the poems focus on benefits women stand to realize from shortterm strategies, they concentrate on a select few of those potentially available. They disregard two of those frequently mentioned by evolutionary researchers and theorists, namely, resource extraction and mate switching. ${ }^{39}$ As already observed, her women express no anxiety about their material welfare, and they do not regard temporary partners as sources of money or gifts. Generally unattached, they demonstrate no interest in future long-term commitment. Hence, they do not use short-term sex as a means of attracting permanent mates, securing backup mates, or replacing current long-term partners with more appealing alternatives. ${ }^{40}$ Instead, they focus on benefits unrelated to commitment: mate quality (and variety), sexual gratification, self-esteem, and autonomy.

38 Buss, Dangerous Passion, 176-79.

39 Buss, Evolution of Desire, 235, 237.

40 Buss, Dangerous Passion, 163-69. 
Millay's women stress the physical appeal of the men they choose. Despite their evident disinterest in procreation, they are selecting affair partners with characteristics associated with genetic quality: men likely to contribute to their fitness if insemination should occur. Their preference for physically superior specimens is motivated by adaptative considerations they do not consciously contemplate. According to the so-called good genes hypothesis, women often select as short-term partners genetically superior men who would be unavailable to them on a long-term basis. The costs to women of these brief encounters may be offset, evolutionary theorists suggest, by the possibility of bearing offspring who carry some of those genes. Since men typically lower their standards when seeking temporary partners - women to whom they make no commitment and in whose offspring they will invest minimally, if at all—such liaisons can promote the reproductive goals of both participants. ${ }^{41}$ Uncommitted sex allows a man to increase his fitness, at least in terms of quantity, without paternal investment; it allows a woman access to genetically more desirable men than those she is likely to attract as long-term mates. For members of both sexes, additionally, a multiplicity of mates secures genetic diversity in offspring, a "bet hedging" advantage "in the face of changing environments." 42 Studies of misassigned paternity indicate that women employ a mixed strategy relatively frequently, obtaining enduring commitment from one man, then cuckolding him with short-term partners manifesting better-or at least different-phenotypic characteristics. ${ }^{43}$

Women identify genetic quality by relying on a variety of cues. Physical symmetry, a "heritable marker of fitness," is particularly important. Symmetrical men "tend to be more muscular, vigorous, larger in size, more physically healthy, more mentally healthy" than less symmetrical rivals. ${ }^{44} \mathrm{~A}$ woman's decision to risk uncommitted sex with a facially and physically well-endowed man indicates that she is responding to such cues, almost certainly without conscious analysis of the underlying genetic logic. The women Millay portrays in her poems conform to this pattern, choosing short-term partners they describe as extraordinarily good-looking. One extols, for example, the "unimpeachable body" of her lover, together with his facial "loveliness" ("What's this of death,"

41 Buss, Evolution of Desire, 90.

42 Gangestad, "Evidence for Adaptations for Female Extra-Pair Mating," 40.

43 Buss, Evolution of Desire, 235-35; Dangerous Passion, 171.

44 Buss, Evolution of Desire, 236. See also David C. Schmitt, "Fundamentals of Human Mating Strategies," in The Handbook of Evolutionary Psychology, ed. David M. Buss (Hoboken, NJ: John Wiley and Sons, 2005), 273. 
lines 7,12 ). As she and other female personae emphasize, a partner's outstanding physical appearance is a source of pleasure; it stimulates desire. Clearly it functions as an important criterion in their selection of temporary partners.

Examples abound throughout Millay's oeuvre. The speaker in "And you as well must die" rhapsodizes over her partner's "beauty": his hand is "flawless," his head "perfect" (lines 2, 3). He possesses "a body of flame and steel": muscular and well-conditioned (line 4). In "Theme and Variations," a woman intent upon discarding a lover confesses that his extreme good looks present an obstacle to her intended departure: enchanted still by "that face," she can let him go only by courting "blindness" - that is, deliberately disregarding his exterior appeal (II, lines 17, 18). She concedes that his appearance, rather than other traits, motivated her to take up with him in the first place; thus she confirms that physical attractiveness functions as an important element in short-term female choice. "These eyes ... let him in," she laments, "not you, my guiltless heart" (II, lines 15, 16). In order to release herself from an unsatisfactory relationship, she must somehow exorcise awareness of his appearance: "these eyes, let them erase / His image," she commands (II, lines 17-18).

Continuing this theme from a slightly different perspective, another speaker informs her temporary partner that his physical attractiveness is essential to her passionate response to him: "Were you not lovely I would leave you now," she blithely assures him, deliberately emphasizing disinterest in his qualities of character as well as disdain for mutual long-term commitment ("Oh, think not I am faithful," line 3). Physical appearance, she announces, is a primary consideration in her selection of partners: "after the feet of beauty fly my own" (line 4). Here, again, hyperbole functions in part to satirize male tendencies and strategies. Millay's personae mimic men's well-known, often criticized high standards for physical beauty in women by making equally rigorous demands for good looks in their male partners, including threats to leave if and when those looks should fade.

In preferring facial beauty and a low waist-to-hip ratio in the women they court, men are responding, of course, to important cues to youth and fertility: they make mating choices that tend to promote reproductive success. ${ }^{45}$ Despite conspicuous disregard of the topic of pregnancy, female preferences presented in Millay's poems similarly implement a potentially beneficial reproductive strategy. Analysis of "dad and cad mating strategies" indicates that mating with "bad boys" (i.e., non-investing and unreliable men) generally represents a bid 
for genetic fitness. ${ }^{46}$ Like men who command special status and resources, unusually attractive men obtain sexual access to women much more easily than do their average-looking competitors. Handsome men's appeal to women offers them frequent opportunities for short-term sex, opportunities which research shows they tend to exploit. ${ }^{47}$ If conception should occur, the temporary female partners of these much-prized men may reap benefits in the shape of highquality offspring. Such offspring may include so-called "sexy sons": male offspring whose above-average physical attractions will enable them, in turn, to implement short-term sexual strategies effectively, thus enhancing their mother's genetic legacy. ${ }^{48}$ Female partners of "cads" risk incurring heavy costs, of course, since the men they prefer are unlikely to linger or to invest. Women who reject long-term commitment for themselves, as so many of those depicted in Millay's poems conspicuously do, are free to disregard such costs. With their often-stated demand for male "loveliness," Millay's women are choosing men whose mate value is high and whose motivation for commitment accordingly is low. Shortterm strategists by personal inclination, philosophical conviction, or both, they revel freely in the erotic intensity inspired by extraordinarily handsome partners.

The speaker in "She Is Overheard Singing" forthrightly explains the attractions of the stereotypical caddish male. She contrasts her partner with those of other women, emphasizing the dullness of the men her acquaintances have selected. Agatha's man is "a hug-the-hearth"; Mig's man is "good as cheese"; Joan's man is "a putterer" (lines 3, 5, 37). Prue's man is "patient," and "asks not when or why"; Sue's man is "like good jell- / All one colour," while Mig's man doesn't "think at all / What's to come" (lines 33-34, 17-18, 19-20). The homely analogies used to describe these men underline the dreariness of their virtues. They are dependably committed, to be sure, but devoid of physical energy and mental keenness. Though they are "honest" and "gentle," qualities their women appreciate and laud, these men lack the ability to excite or intrigue their female partners $(6,21)$. The speaker rejoices in her own choice, a man who is neither homeloving nor reliable. "My true love's a rover!" she exults; "my dear lad's a liar!"; "my true love is false!" (lines 4, 8, 40). Combining endearments with ostensibly

46 Daniel J. Kruger, Maryanne Fisher, and Ian Jobling, "Proper Hero Dads and Dark Hero Cads: Alternate Mating Strategies Exemplified in British Romantic Literature," in The Literary Animal: Evolution and the Nature of Narrative," ed. Jonathan Gottschall and David Sloan Wilson (Evanston, IL: Northwestern University Press, 2005), 226, 228.

47 Kruger, Fisher, and Jobling, "Proper Hero Dads"; Schmitt, "Fundamentals of Human Mating," 273-74.

48 Buss, Dangerous Passion, 163-64; Kruger, Fisher, and Jobling, "Proper Hero Dads," 227. 
negative characterizations, she highlights the paradoxical appeal of the outrageously handsome, notoriously inconstant men Buss dubs "'studly' charmers." ${ }^{9}$ Although the poem provides no physical description of the speaker's partner, his obviously high genetic quality is the source, implicitly, of his pop-star-like effect on the opposite sex. The speaker avers that all the women she knows, no matter how much they claim to value the staid devotion of their mates, "would give the life they live / For a look from the man I kiss" (lines 23-24). The reference to kissing indicates that the man's bad-boy traits stimulate passionate response, possibly against many women's better judgment and conscious wishes, promising erotic fulfillment. To have been chosen by him, moreover, validates the speaker's own mate value: desired by many women, he casts "his eyes about" with "cold" calculation, selecting only a "few" as worthy of his attention (lines 25, 26). She accepts his inconstancy as further proof of his quality, admitting without reproach that "he'd slip me clean for a nun, or a queen, / Or a beggar," (lines 27-28). This man has no need to sit at home devotedly and putter. To enjoy the sexual attentions of such a man, however briefly, is indisputably worthwhile, Millay's persona concludes: she chooses erotic excitement over domestic tranquility. The poem provides remarkably explicit illustration of the dad-cad dichotomy Darwinian researchers have identified in human mating strategies. Very evidently, it is not necessary for women to think consciously about the genetic superiority of men they find sexually exciting. The characters in Millay's poem are oblivious to ultimate ends, such as the high-quality offspring a handsome rogue might sire. They concentrate, rather, on the pleasures of his "kiss," i.e., his ability to satisfy proximate desires.

As foregoing examples indicate, a preference for short-term partners manifesting high genetic quality goes hand-in-hand with another benefit prized by women depicted in Millay's poetry: sexual gratification in and of itself. Because cultural norms have operated to suppress and deny women's sexuality, including any predilection for sexual variety, a frisson of the forbidden marks Millay's portrayal of lusty adventuresses. Recent research supports the conclusion, however, that though her depictions may be deliberately hyperbolic, they are essentially accurate. Studying "women's perceptions of the benefits of affairs," Buss reports, "sexual gratification was at the top of the list." 50 The women in Millay's poems similarly identify "passion" as the primary motivation for temporary liaisons ("We talk of taxes," line 9). “The desirous body's

49 Buss, Dangerous Passion, 164.

50 Ibid., 170. 
heat" propels them into relationships promising sexual fulfillment ("Yet in an hour to come," line 10).

Another benefit associated with short-term sex, often observed in Millay's poetry, is enhanced self-esteem. From a Darwinian perspective, the utility of positive self-assessment in the social environment is clear. Because "self-esteem makes you behave in ways befitting an esteemed primate," it may inspire confidence and win respect (particularly, perhaps, if the affair precipitating a rise in self-esteem is not discovered). ${ }^{51}$ Affairs provide women with opportunities for upward re-evaluation of their personal attributes, Buss reports. The novelty and intensity of an affair-partner's attentions reassure a woman that she is "beautiful," "important," "intelligent," and "sexy." ${ }^{52}$ Buss speculates that boredom with a relationship or a routine "grown stale" may explain this "surge" in feelings of self-worth, which he likens to the effect of "a wonder drug." 53 In Part V of "Theme and Variations," the speaker compares herself to a "hall," now vacant because no lovers remain to populate it (line 5). She emphasizes the high quality of men whom she has by turns "loved badly" or "too soon," claiming nevertheless that "the very rafters of this room / Are honored by the guests it had" (lines 3, 4, 11-12). Brief and imperfect though they may have been, the affairs have exalted her: she has been partnered with "gentry" (line 15). Having increased the value she places on herself, these previous relationships enable her to dismiss her current paramour, the "only" one out of so many to prove "unworthy" (line 13). He is a peon, figuratively, in comparison with her more elite "guests," and the self-assurance she has won from their attentions proves enduringly beneficial (line 12). Other poems generate similar analogies between high self-esteem and aristocratic status. Frequently comparing themselves to queens or goddesses, Millay's female personae confirm the association between short-term sex and feelings of self-worth. Love affairs can generate a sense of importance equivalent to that accompanying social and political prestige.

The higher the quality of the short-term partner, evidently, the more powerful a jolt to self-esteem an affair can provide. It appears that the benefits available to female short-term strategists may be mutually reinforcing. A preference for exceptionally good-looking men, such as Millay's women exhibit, not only secures probable genetic payoffs for potential offspring (Benefit Number

51 Wright, Moral Animal, 244.

52 Buss, Evolution and Desire, 238-39.

53 Ibid., 239. 
One), it promotes erotic fulfillment (Benefit Number Two), since these irresistibly handsome, universally desired men stimulate arousal and generate sexual excitement. Additionally, the attentions of such men foster feelings of confidence and self-worth (Benefit Number Three), a psychologically uplifting and socially useful effect. Millay's women stand to enjoy a constellation of smoothly intertwined benefits from their predilection for flings with heartbreakingly attractive men.

Tightly interwoven into this constellation of advantages is a final, crucial benefit women can obtain from short-term strategies: personal autonomy. Eschewing commitment, women in Millay's poetry escape the proprietary domination typically imposed by men on their long-term female partners. Temporary involvements offer them scope for assertive behavior and sexual fulfillment, including choice in partners. Although history and literature are rife with examples of women who are duped and exploited by short-term seducers, Millay's women regularly seize control, frequently dominating the men with whom they are sexually involved. Even when affairs end sooner than anticipated and against their wishes, they avoid positions of helplessness or vulnerability. The few wives depicted in the poems likewise refrain from submissive compliance with husbandly possessiveness; instead, they affirm their autonomy by indulging freely in extramarital liaisons.

Throughout Millay's work, female agency appears as a consistently important theme. ${ }^{54}$ That agency is well served, she implicitly argues, by shortterm affairs. These discourage emotional investment, permitting women to extricate themselves easily, control the timing of break-ups, and elude subjugating entanglement. "And if I loved you Wednesday, / Well, what is that to you?" one speaker demands. By Thursday she has withdrawn that love ("Thursday," lines 1-2). She chides her erstwhile partner for "complaining" about her abrupt defection, making plain that his reaction is of no concern to her whatsoever (line 5). She has moved on, emotionally, and the "love" of yesterday means nothing to her now: "what / Is that to me?" (lines 7-8). Here readers watch a woman toying with a man's affections much as men traditionally have done with women's. She is the one whose emotional detachment wins her control in the relationship. Her capacity for switching feelings rapidly on and off enables her to dominate her partner, and she revels in her role, deriding her lover's

54 "Of greater importance than any particular ethic of Edna Millay's-e.g., a woman's right to be as inconstant in love as a man-is the larger concept of freedom implicit in her work." Janet Gassman, “Edna St. Vincent Millay: 'Nobody’s Own,” 310. 
clinginess. ${ }^{55}$ Like the speaker in "I, being born a woman," she treats her partner with an exaggerated heartlessness, underlining her high-spirited celebration of female control.

As poem after poem illustrates, concentrating on the time-limited nature of a relationship helps a woman to retain the upper hand in it. Anticipating the end of an affair even in the "pearled and roseate" days of its beginning discourages the development of long-term expectations ("What thing is this," line 7). Thus guarded from anxieties, women can yield to romantic "bliss" while remaining in charge of their own destinies (line 12). They can cherish freely the ecstasy inherent in "fleeting" romance, no matter how "clandestine" or "brief" that ecstasy may prove, praising it in the highest terms: "I do cry holy, holy" ("When did I ever deny," lines 8, 10, 9). When necessary, they remind themselves that any affair, prolonged beyond its pre-ordained limits, is as offputting as "stale patchouli" ("I know the face of Falsehood" line 14). They reject the "unwelcome" crumbs of a partner's cooling affection: "Love's bitter crust" ("That Love at length," line 7). Faced with the "ebb of love" and imminent conclusion of an affair, consequently, a woman is well advised to end it herself, retaining power in a deteriorating relationship by being the first to defect ("Theme and Variations" VII, line 6).

The speaker-protagonist in Fatal Interview, who fears from the outset that she will be abandoned by her extramarital partner, thus insists that his departure is her "choice" rather than his: "not from your temper does my doom depend" ("I know my mind," lines 1,2). She speeds her increasingly restless lover on his way out the door instead of pleading with him to remain, a tactic that secures her a say in events. "Love me no more," she commands him, when she begins to "surmise" that her "kisses" no longer thrill him ("Love me no more," lines 1, 6, 7). Shrewdly she orders him to do what she suspects he already intends, thus replacing his volition with hers. Like so many of the short-term strategists Millay portrays, this character values her power in the relationship at least as much as the sexual fulfillment it provides. Her goal is to act rather than to be acted upon. Announcing the break-up as her decision, she avoids assuming an abject role.

The Darwinian significance of Millay's focus on autonomy is clear. All animals seek, as permitted by their varying intelligence levels, to direct their

55 "One of Millay's strategies for subverting the traditional love lyric," Ernest J. Smith rightly observes, "is to have the woman speaker emerge from the affair whole, rather than in a state of disintegration." “How the Speaking Pen Has Been Impeded': The Rhetoric of Love and Selfhood in Millay and Rich," in Millay at 100: A Critical Reappraisal, ed. Diane P. Freedman (Carbondale and Edwardsville: Southern Illinois University Press, 1995), 48. 
individual quests for survival and reproduction-deciding, for example, what to eat, when to mate, when to fight, when to run, or where to hide. Each such decision affects the ultimate genetic legacy of the creature making it. Given highly developed brains, multifaceted behavioral options, and complex cultural environments, human beings command more conscious decision-making powers than any other animal. Poised to take charge of their life histories within the bounds of their physical and social environments, individual members of the species struggle mightily to retain freedom of choice and action. From an evolutionary psychological perspective, understandably, "the desire for control is the fundamental motivation underlying the behavioral and psychological development of human beings." 56 The systematic domination of women by men contradicts this basic human desire. Patriarchal compulsion and custom radically restrict women's ability to shape their own destinies, their sexual destinies in particular. ${ }^{57}$ Resistance to such restriction is inevitable. ${ }^{58}$

Millay's deliberately provocative presentation of sexually assertive, strong-willed women is a literary manifestation of such resistance. ${ }^{59}$ Delighting and appalling her readers, she peoples her poetry with women who orchestrate their sexual lives as they see fit, unequivocally announcing and expressing their innate ardency. They utilize short-term strategies, by preference, because these maximize sexual fulfillment while minimizing threats to personal liberty. Highlighting proximate influences on behavior (the pleasure of erotic activity) while shearing these from their ultimate function (the passing on of genes through children), Millay brazenly draws attention to benefits available to women who reject long-term, exclusive commitment. With her bold, often exaggerated depictions of erotically vital, commanding women, she ridicules conventional images of feminine submission and sexual reserve. Her poems expand and correct prevailing conceptions of female human

56 Geary, Male, Female, 161.

57 Hrdy addresses the "evolutionary implications" of curtailment of female sexual activity. Research indicates that restriction of female mate choice proves dangerously disadvantageous to a species, thereby confirming the "importance of female autonomy in reproductive decisions." Mother Nature, 41, 42.

58 Hrdy, Mother Nature, 87; Frederick, Reynolds, and Fisher, “The Importance of Female Choice," 318-24; Buss, Evolution of Desire, 13.

59 Clark notes that Millay "seems quite conscious of the political ramifications of her work." "Uncanny Millay," 25. Colin Falck, too, discusses her conscious "repudiation of the conventionally institutionalized subjection of women." "Introduction: The Modern Lyricism of Edna Millay," in Edna St. Vincent Millay: Selected Poems, ed. Colin Falck (New York: HarperCollins, 1991), xxiii. 
nature in important ways, undermining the rationale for gender-based sociopolitical discrimination.

At the same time, unobtrusively yet unmistakably, her poems protest biological obstacles to women's sexual freedom and personal autonomy. Chief among these are sexual dimorphism (the relatively greater physical strength enabling men to coerce women), intersexual conflict (with emphasis on strategic interference by men), and reproduction itself (pregnancy and offspring). Millay's celebratory presentation of female agency presupposes elimination of these and related impediments to its full expression. Insofar as these impediments are ineradicable, achievement of her most deeply cherished goals must remain imperfect. Only in the imaginative realm of art can proximal satisfactions be altogether decoupled from ultimate functions, or behavioral choices from evolved adaptations. Like many other writers, Millay invokes the power of imagination to construct an alternative environment, satisfyingly counterfactual in significant details. In so doing, she illustrates the unique capacity of the human animal "to rebel against the dictates of the genes." 60 Because her repudiation of biological realities is covert, taking the form of silent denial rather than open complaint, it may not be recognized by readers for what it is: tacit admission that social change alone, however necessary and desirable, would be insufficient to secure women the idealized sexual freedom and personal autonomy she so passionately imagines.

60 Dawkins, Selfish Gene, 59-60. 